\title{
Book review: Triumph of the City, Edward Glaeser
}

\section{Book review: Triumph of the City}

Edward Glaeser

Penguin Press, 2011

ISBN: 978-1-59420-277-3

Edward Glaeser's Triumph of the City (2011) offers an indepth look into the ingredients that can make a successful city, as well as those that can precede a city's downfall. His book examines how cities came to be, and how, despite complete overhauls in culture, medicine and technology, cities continue to be the influential driving force of the world. Glaeser also discusses the ways that cities can continue to thrive in the future, and how they must lead by example in turning both urban metropolises and rural outcrops into more environmentally friendly places. Using several real-world examples, the author emphasizes three main topics: why urbanism trumps ruralism, what makes bad and good cities, and how mankind can continue to improve upon them. Some of Glaeser's points are disputable, but overall Triumph of the City provides an excellent roadmap on how to design a prosperous, just, and successful city. Glaeser's background as a leading scholar on urban economic issues at Harvard University helps to create a book that touches on popular science, while being informative and academic enough to find relevance in an economics or urban planning classroom. The topic of cities is most certainly timely, accompanying the City 2.0 prize by TED (2012) as well as other topical books (Kennedy 2011).

So, why cities? After being villified in the late 19th and early 20th century, cities have received much praise, notably thanks to Jane Jacobs' seminal work (Jacobs 1961). On a more contemporary note, much emphasis is currently put on cities and their designs as a solution to curb our carbon footprint (Kennedy et al. 2009) (more on the subject later).

Glaeser asserts that cities' primary function is, and always has been, proximity. New York started out as a shipping hub due to its convenient location along the New World's east coast. This, in turn, prompted manufacturing companies to set up shop around the harbor, so that they could have direct, inexpensive access to incoming cargo, and thus the city was born. The author explains how many cities sprouted in differ- ent ways, but with the same general purpose: the convenience of proximity benefited all parties involved. But what really allows a city to thrive is that it brings people-and ideastogether, echoing Florida's work and shown by Bettencourt et al. (2007). Technology has largely done away with some needs for physical adjacency; shipping costs are low and airplanes are fast: technology is apparently "the death of distance" (p. 4). However, one thing that Glaeser stresses can never be done away with is the value of being face-to-face. Even though innovations like telephones and video chat theoretically eliminate the need to be in the same room (or city) as someone, they are far better suited to complement meetings of the minds rather than replace them (p. 34).

The author has explained the origin of the city, but it is not yet evident whether it is truly "better" than exurbs. As previously mentioned, corruption and crime are rampant in some places, and they can have debilitating consequences. Glaeser recalls the findings from economist Gary Becker, who estimated a 10 percent increase in policemen results in a 5 percent decrease in crime. On the surface, this does not appear to be an efficient use of manpower, but other factors like conviction rate and severity of punishment do help to further lower crime rates (p. 111).

Disease and pollution have historically been predominantly found in cities. Glaeser believes that the public sector has the responsibility, and often the ability, to remedy this. The most important combatants against the spread of disease are clean drinking water and proper sanitation. In the modern age, nearly all cities in developed countries and many cities in developing countries are able to provide these, while poor and rural villages may not be so lucky. Government's primary obligation is to its people, and these are the most basic needs of all —if these fundamental needs are not met, then citizens will leave for places where they will be. As for pollution, Glaeser reveals some interesting statistics that suggest cities are in fact far 
"greener" than just about anywhere else. "The average household living in [an area] with more than ten thousand people per square mile uses 687 gallons of gas per year, while the average household living in an area with fewer than one thousand people per square mile uses 1,164 gallons of gas per year" (p. 207). As now commonly accepted and initially expressed by Newman and Kenworthy (1991), denser and more compact cities tend to require less energy for transportation (i.e., markedly shorter distances for the home-work trip). Meanwhile, the majority of those in the suburbs must cover great distances by car.

One point of contention is Glaeser's claim that cities do not make people poor, but rather that they attract poor people ( $\mathrm{p}$. 70). From this, he suggests that cities are therefore seen as a land of opportunity for the poor, a place where they can make a living and rise up out of poverty. While this assertion is undoubtedly true in some cases, especially in developing countries with high urbanization rates (World Bank 2013), the cycle of poverty in the US is a well-known issue, where many have been living in a state of poverty for several generations. As residents of Chicago, the authors of this review can personally attest to this phenonemon, which also appears in the U.S. Census Bureau (2010). This means that most poor are not "new arrivals" looking for a fresh start, but rather that they are an established, and often growing, aspect of city life. Glaeser does make a salient point, however, which is that it is almost always better to be poor in a city than in a rural area.

Aside from the issues already mentioned that contribute to making a city "bad," the biggest signs of a bad city are urban sprawl (from an environmental standpoint), and urban exodus (from an economic standpoint). Two real-world examples of this are Houston and Detroit. From an economic standpoint, Houston is quite successful; it is growing, it has low unemployment rates, and it has affordable housing (p. 183185). Nevertheless, the local government has greatly encouraged home ownership, which in this context pushes Houstonians to move to the suburbs (by the millions), thus massively increasing the number of cars and the miles driven on Houston's highways. Detroit, on the other hand, has been rapidly declining to the point of having to declare bankruptcy. Its population sits at around half of what it was at its peak decades ago. Detroit's housing is also quite affordable, but for a very different reason, i.e., little or no demand. Glaeser recounts how Detroit's urban exodus is due to one bad governmental decision after another, going all the way back to the beginning of the mass-produced automobile industry. Glaeser further explains that while Ford's innovations were hugely successful for Detroit (and America) at the time, the incentive to bring in unskilled workers-a direct contradiction to the concept of attracting people with ideas-would ultimately be Detroit's downfall. Detroit had all its eggs in one basket and once outside competition showed up, there were no other sectors to pick up the slack. Local government then naively followed the "build it and they will come" mantra, and wasted millions of dollars on ineffective public projects like the People Mover, which have done nothing but set the city back.

Paris and New York seem like shining examples of what a city should be, but they share one serious problem: excessive costs of living (Economist Intelligence Unit 2013). These high costs are due to high demand and little supply. In their most desirable neighborhoods, development is severely regulated. There are strict height limits on Parisian buildings, and both cities have out-of-control preservation regulation that prevents all kinds of old structures from being destroyed and replaced by gleaming skyscrapers. This results in skyrocketing housing costs, and forces people away from the city.

In similar fashion, coastal California has inadvertently pushed inhabitants toward more sprawled areas by imposing strict regulations on new construction and by constantly designating new land as "protected" (p. 211). While such restrictions appear noble on the surface, they have adverse consequences. The region sits in a temperate climate that would theoretically reduce heating and cooling emissions, but by forcing would-be inhabitants to look elsewhere, they have only contributed to increased consumption elsewhere.

A truly great city encourages development, which keeps housing costs low, and simultaneously prevents urban sprawl and congestion. It must be business-friendly, so that companies from all sectors are encouraged to set up shop and create a competitive environment that keeps consumer costs low, and creates jobs so that people from all over the world can come and share ideas. This in turn promotes education, which combats corruption, which then helps keep cities clean and helps fight crime. To further fight congestion, Glaeser has suggested congestion pricing, which is in use to a certain extent in places like London and Singapore. This simple concept generates revenue and productivity by charging commuters for the environmental costs of driving, while reducing traffic. The author stresses that congestion pricing should not, however, be used to fund transportation infrastructure, as this only promotes more driving and magnifies the problem it was meant to solve (p. 267). In short, as Glaeser outlines in chapter 9, successful cities must be well-managed and promote education, consumerism, and growth.

Only then can a city truly triumph. 


\section{References}

Bettencourt, L., J. Lobo, D. Helbing, C. Kuhnert, and G. West. 2007. Growth, innovation, scaling, and the pace of life in cities. In Proceedings of the National Academy of Sciences, volume 104, pp. 7301-7306.

Economist Intelligence Unit. 2013. Worldwide Cost of Living 2013. London, UK: The Economist Intelligence Unit.

Florida, R. 2002. The rise of the creative class: and how it's transforming work, leisure, community and everyday life. New York, NY: Basic Books.

Glaeser, E. 2011. Triumph of the city: how our greatest invention makes us richer, smarter, greener, healthier, and happier. New York, NY: Penguin Press.

Jacobs, J. 1961. The Death and Life of Great American Cities. New York, N.Y.: Random House.

Kennedy, C. 2011. The Evolution of Great World Cities: Urban Wealth and Economic Growth. Toronto, ON: University of Toronto Press.

Kennedy, C., J. Steinberger, B. Gasson, Y. Hansen, T. Hillman, M. Havránek, D. Pataki, A. Phdungsilp, A. Ramaswami, and G. Mendez. 2009. Greenhouse gas emissions from global cities. Environmental Science and Technology, 43:7297-7302.

Newman, P. and J. Kenworthy. 1991. Transport and urban form in thirty-two of the world's principal cities. Transport Reviews: A Transnational Transdisciplinary Journal, 11:249.

TED. 2012. TED prize: Wishes big enough to change the world - announcing the 2012 TED prize winner - the city 2.0. Web page. URL http://www.ted.com/pages/ prizewinner_city2.

U.S. Census Bureau. 2010. American community survey: Geographical mobility by poverty status (5-year estimate). URL http://factfinder2.census.gov/faces/ tableservices/jsf/pages/productview.xhtml?pid=ACS 10_5YR_B070128prodType $=$ table.

World Bank. 2013. Urban population (percent of total) World Bank data catalogue. URL http://data.worldbank. org/indicator/SP.URB.TOTL.IN.ZS. 